\title{
User profiles: from a qualitative case study approach to providing a better service
}

\author{
Paula Sequeiros ${ }^{1}$ \\ ${ }^{1}$ Associate Researcher to the Instituto de Sociologia, Porto University
}

Abstract: User profiles were designed through a qualitative approach to a case study of a public library, starting from an analysis of space social relations, of how the building's design shaped reading practices and of how space was actually being used.

Keywords: user profiles; case study; space relations; building, architecture, qualitative methodology; public libraries; Portugal

Acknowledgement: my special gratitude to Silvia Grünig, architect and lecturer, with whom I did a comparative study of this and another library (unpublished) and who generously contributed with her critical vision to the final form of this paper.

\section{Introduction}

Library buildings are artefacts that shape reading practices, allowing for or inhibiting the appropriation of space and the creation of particular reading atmospheres. We relied on previous theory on how space and social relations interact in the production and reproduction of space, Lefèvbre (2000), and on how users appropriate and practice it, eventually circumventing constraints, Certeau (1990).

An integrated, intensive approach was used in order to analyse and interpret Geertz (1973, 3), Blumer (apud Becker, 1996) - not only those practices but also their wider context of relations and processes, as well as the socially constructed meanings attached to them by subjects, for a comprehensive understanding of the whole social reality, Blumer (apud Donmoyer, 2000, 49). An interesting, rich case was picked and a theoretical sample constructed according to the perceived diversity in that library - gender, age, social class, ethnic origin, disabilities: 28 users, one library manager, one assistant librarian, the maintenance supervisor, and the architect were interviewed.

An empirical research was designed, focusing on users' real practices, and taking into account social inequalities as well as power relations. Within a qualitative framework, and with a strong ethnographic support, observation Seale (2004) - and interview - Kvale (1996) - techniques, were used focusing on users actual practices and discourses, as well as on those of librarians, staff and architects, along side with the building analysis. An analysis of children's drawings was also used to supplement their interviews.

Envisioning public reading as a public service, I assume the favouring of the provision of democratic spaces, Calhoun (2005), to be enjoyed as places of encounter and discovery, be it for cultural, leisure, information or learning purposes, as well as a compromise with the intentionality of the constructed object and of the purposes of the research, Haraway (1991).

\section{The Almeida Garrett Public Library}

Inaugurated in 2001, the library is inserted within the largest public park in the city of Porto, dated from the $19^{\text {th }}$ century. Its romantic design includes rose 
gardens, lakes, gigantic trees, a magnificent view over the river, hosting a sports pavilion, a restaurant, and a children's park. The area is well served by public transportation, half way from both city centres. The library is an attractor: only a half of the interviewed resided in the metropolitan area.

According to the architect, José Manuel Soares, his wish was to bring the garden into the library, while not imposing a building on it and to control the incoming light without blocking a relation with the surroundings or veiling the particularity of the place. Conceptually, the architectural programme stressed the importance of free access to stacks, and demanded a library for «those who are about to have a first contact with books», as well as for students, where one could walk in or out freely, in continuity with the public space. His main concerns were to conceive a space «ready to be used in different ways», «according to each time period», but «still able to go on being adapted», allowing for small spaces to be appropriated and preventing dispersion, a space that could be «clearly put under questioning». He also remarked how all departments, the Culture councillor and the National Book Institute cooperated in the project, and on how European funding allowed for high quality materials and innovative solutions.

The library occupies two of the four levels, an art gallery and a hall the others. There are separate areas, although not completely isolated, for general reading, for children, series, multimedia and Internet. The architect tried to avoid a hierarchical distribution of services by the different floors, the hierarchy of spaces was strategically used in creating decreasing noise levels as one progresses in the building, but still allowing for a vision of the whole space.

\section{How space, in general, is evaluated and sensed Feeling the space}

Users took some trouble in reflecting and defining how that space made them feel. Further to the initial difficulty in referring to something simultaneously abstract and concrete, Lefèbvre $(2000,100)$, they unanimously praised the light and transparency and the integration in the park. The surrounding garden was frequently mentioned to state how the building's insertion was very positively valued, although just the children stated to use it frequently. Adults felt that it transmitted, nevertheless, a calming atmosphere.

The location was also appreciated, almost all the interviewed readers use public transportation to get there, some living nearby go on foot.

We could observe how readers weaved their «reading cocoons», perhaps lighter than the front glass façade, but still encapsulating their activities. Their gazes abstracted - by an absent impertinence, Certeau (1990) - desensitized from the surroundings: two peacocks paced along the the windows sills during one of the interviews, no one seemed to notice them.

Emotionally, although indulging in diverse activities, they collectively weave a reading climate, a product of the social relations reflected in a practiced space Lefèvbre (2000). Tranquillity, organization, concentration, the possibility of integrating a stimulating intellectual labour ambiance, all were signalled out as valued characteristics - a climate they don't get if staying home.

And going to the library is not necessarily an individual act: children are always accompanied by adults, some adults and adolescents come in pairs or groups. At times a certain small talk goes on, maybe around the latest news headlines, as was the case with the raise in the price of bread. Co-presence is valued, even when not addressed to, familiar faces are registered and discreetly followed.

The need for privacy is differently felt, seeming to vary according to living 
habits, at work, home, according to gender or social class: a young woman dislikes being stared at «in an unpleasant way» by men; the homeless reader thinks it's only natural that others try to peep into the Sites he's visiting, «they're not going to take any bite out of me!»; the sole idea of a lack of privacy in the library made the young couple, sharing an apartment with twelve other family members, laugh out loud. Almost all referred to this co-presence as a tacit agreement - a relational contract, Certeau (1990): being in a public space presupposes some concessions over the space personally reserved.

Personalization, privacy, surveillance

«I need my private space and live amid a lot of people», a therapeutic community. In this library reading «is never-ending, is finding the words for things, resting and reflecting [...,] very pleasurable». «If I stopped leading this life I'm used to in public spaces, I'd be surely loosing a certain pleasure and harmony I long for».

The need to socialize is clearly felt by many. Proximity without propinquity according to Park's expression, apud Tonkiss (2005) - the withdrawal inherent to reading overlaps with the need for privacy characteristic of urban lives.

Personal, private space created by reading is like a bubble, soft but protecting. The rules of co-reading are passed along with learning to read: this practical knowledge - the habitus of Bourdieu (1979) - entitles one, "naturally» not expect to be disturbed. The most annoying intrusion appeared to be cell phones ringing, which might draw users to require staff intervention.

Surveillance activities by security guards and the installation of cameras which nobody had spontaneously noticed - are felt as protective: the library is felt as a safe space. And so is the surrounding garden, except for a blind reader who has trouble in circulating through its winding paths and reach the entrance, or for an elder reader with mobility issues who keeps alert while crossing it.

For a few readers, with personal histories of surpassing barriers to become library users, their present situation was felt as an accomplishment: a woman, daughter of manual workers who toiled to get their children educated, and who became blind; a retired male reader, attending the Senior University, who rejoices for seeing young people studying, a chance he didn't get in his days.

Now let's have a look at how different users appropriate this space. Keeping in mind the library's insertion in the park, some metaphors Haraway (1988) arose when aggregating and classifying them.

\section{User profiles identified}

\section{Bees - Occupational users}

To actively occupy their time in a useful way inside the library, presently working for a salary or not, is this group's purpose.

They may stay for the whole day, several days a week: «I leave when the lights go off, [when] I have no choice!... Now my day ended, I may focus on something else» (male reader, 34, unemployed). A female assiduous reader belongs to the so-called residents, the local librarians' nickname. «The day goes by more quickly, it's more productive» (female, 28, unemployed). Their stronger motivations: to profit from an environment favouring their study and free resources. Their common feature: to actively be occupied in tasks, organized and planned in detail, from subjects to schedules. They research and write on matters according to their education or curiosity, shape up for job competitions. Unemployed or retired are words avoided in their personal narratives, surely avoiding the social stigma; but their disposition and a work ethics, adapted to their present situation, seem all to shape their practices. Were 
they at an office or university, we would not hesitate to state they are working. They are six young adults, half hold a degree - they come to enjoy the company of others and the togetherness, Bakardjieva, (2004), of like-minded that helps discipline their work; one is an elderly citizen, strolling from one continent to another, who profits from Internet access to update his biographical Site. For half of them using the Net is the main purpose of the visit, two brought their portables, and listen to music with earplugs. Two others referred the Net as a secondary resource. Other main activities vary: reading newspapers, writing pieces on the city's History, a female reader is a multiple user (varied resources); one studies, another borrows books and trains computing and language skills, profits from an enticing studying environment, considered more stimulating than the therapeutic community she lives in.

Their activities stay anchored to the tables; exteriorizing their doings when writing, plugging laptops, changing belongings from one place to another. They occupy the same zones as students and scholars, referred to further on.

\section{Butterflies - Strolling readers}

Unlike occupational readers, they have no specific activity or interest in mind, just want to stroll around and spend time in a pleasant and a accompanied way, although generally not interacting - resembling Wirth's (1964) urban strollers. And strolling take glances at newspapers and magazines, records, Internet pages, books, heading for multiple resources. Less qualified (secondary school or less), they are manual workers, retired, unemployed with different ages.

Most used areas are multimedia, couches, circulating zones. «When I feel low, I get here and it seems I reinvigorate. Crossing that door, this is as if it were my house, my family» - former typographer, 34, unemployed and homeless, comes in one or two hours every day. He enjoys the age diversity, seeing new faces. His homeless companions persuaded him: «you watch a movie and when you go out you feel quite another person!». Watching everything, including cartoons, sometimes peeps in whatever film is already being displayed. And, above all, enjoys reading the newspaper, specially the one he used to work for. Another 50 year old stroller, former car mechanic, acknowledges that others come in seeking «not to be alone», which he himself doesn't admit to be doing. Used to read intensely, «maybe it was a refuge», nowadays has an eye condition, reason why he turns to the Internet, which he can't afford at home.

A 9 year old girl comes every Saturday in the company of an adult sister and an elder brother. Regretting she can't stay longer for the Story Hour - her sister must cook lunch - she reads a little at home; her brother reads a lot, especially before falling asleep and always borrows a film before leaving.

And yet another interesting case: a very young couple comes pushing two baby charts. Both 22 and under the minimum educational level, the mother is enrolling as a reader, he guides her as an experienced user (here and abroad where he was raised). They live in a single room, in an apartment of twelve, several of them unemployed or working in underqualified jobs. They plan to come every Saturday, all four, to use the Internet, which they value for the information they gather on nursing babies, «more than the doctor says», to look for baby games and send SMS. She reads very little, only aloud for the babies. He prefers films and music. They value this wide, clean, ordered space, quieter than a cybercafé, where they find more privacy than at their crowded home. Petit $(2001,118)$ states: «intimacy, interiority, worrying about oneself, all that was not for [the poor], it was a heritage of people with means. [...] The absence of intimacy is perhaps the best poverty indicator, even more than income».

Sparrows - Recreational readers

For this other group the library is mainly a recreational and conviviality space. 
All multiple readers, sometimes they bring their own toys in, attend events,
aloud reading. They may meet and join other children in games, or take part in school visits. Most used zones are the children's area and the multimedia.

«I read grownup books on trucks, at school I only read teaching books, I borrow and play in the computer», where he created his own profile to play regularly - 8 year old boy, coming with his parents from a neighbouring town.

«Here above it's more for reading, down there [multimedia] it's more for leisure, to be more relaxed» - African immigrant, in his forties, comes to the library to profit from his several days of rest. This international truck driver added another library card to those collected in European cities where he lived for short periods of time. He intends to email friends and relatives scattered all over the world, and to spend time enjoying whatever the media (CDs, DVDs and Youtube, magazines, borrowed books). He's the only adult in this group.

As a note we would draw the attention to the fact that, in spite of the promises of a «leisure society» - a never attained reality - or the fact that a growing number of people are being left without paid work, leisure activities still carry the burden of stigma under a dominating productivist ideology. While alienating or consumerist leisure activities are well envisaged, that may not be the case with some activities, which are more tolerated than supported - as a user said you should not do in a library «things libraries aren't meant for».

All the others are children who burst in accompanied by relatives and teachers. We spoke with several of them, aged 4 to 8 , and used their drawings to understand what they think a library is and what they like doing there.

They draw, play computer games, read books or listen to reading aloud. Almost all of them have books at home. They use chairs, cushions or lie on the floor. They know what they're not allowed to do: scribble books - «you must grow up first» - step on top of the tables. They laugh and move at ease, sometimes run. Some are scolded for going up a ramp that leads to the top of the stacks.

On Saturdays, during Story Hour, the reading room becomes too narrow to accommodate all of them and their parents, grandmothers. The temperature rises, books and sheets turn into fans to drive the heat away.

The majority prefers to play with the computer. A 7 year old boy, a multiple reader, draws a library using several crayons at the same time: «books are multicoloured»; several small squares get filled with the alphabet, resembling the computer game he used before, all topped by the word Library; in a corner a small character uses a computer, and above «I read» is inscribed. Outside a smiling bright sun, some stars, and his football club symbol.

Almost all of them also take a walk in the garden or go to the children's park when visiting the library.

\section{Ants - Student readers}

They come to study, sometimes in groups or couples; a great part is still attending their degree classes, one is a taking a Master's, a few already graduated and go on studying themes in the areas they specialized.

They're motivated by conviviality, companionship, a relaxed but still attracting environment - joining others equally occupied stimulates them. The choice for this library and their reading is instrumental: university libraries don't usually allow group study, titles are associated with their courses, don't use much other bibliographic resources. They come mostly after lunch, carrying the books they need, sometimes laptops, some use mobile audio to create an aural privacy - the earplugs also signal that they don't want to be disturbed (Bull, 2006); the isolation propitiated by reading is thus reinforced by this creation of personal, individualized atmospheres. Ages range from 24 to forty something.

They mainly occupy individual tables, the workstations with Internet access on 
ground floor or inferior, and eventually the vacant tables on the extreme end. Sometimes use tricks, Certeau (1990) to create extra space: clothes, bags, books are scattered to occupy more than one place, signalling that they are not willing to share coupled tables; they sometimes frown at people chatting, signalling their labour is being disturbed. They compete for space silent but actively, assumptions on adequate uses (and users) seem to protect their presence before any others, their work being a «natural» enough and sufficient credential. Some express their contentment for an environment that has no complete silence, which would bother them, preferring this light hush-hush as a background.

\section{Owls - Scholar readers}

A small group in this library, they indulge in researching some theme of personal choice or to complete a formal education. They study autonomously, on their pace and appreciate conviviality. As experienced users know every corner and their presence is discrete. Frequently take notes from their readings, write essays. Local History is a common topic among them. Their presence is highly regarded both by other users and staff. They're very likely residents.

An elderly scholar states how it pleases him to find answers for the «doubts that trouble» him, and how he enjoys watching younger people at study.

\section{The residents, a subgroup}

Resident readers behave like habitués, concentrating in the tables surrounding the mezzanine: a privileged spot to control visually the whole space.

This subgroup is composed mainly of scholars but also of occupational readers. Some elder male readers benefit from the special care of a very attentive female librarian: noted absences may trigger further need to be informed about their health. In her words: «this is their second home», «they get accustomed to us and we to them». We noticed that they use the complaints book, a resource scarcely known to others. An extreme case may, in spite of its particularity, depict how they feel entitled to this special attention: an elderly male reader once knocked on the staff entrance carrying his special sofa and asking to have it placed for him besides his usual table.

This long acquaintance, the frequency and duration of their visits, their competition for personal attention, all facilitate that they may act as a pressure group. Counteracting this, we may still hear some commentaries from less skilled personnel, judging them for «not doing a thing in life, besides going there», associating negative values to this form of leisure.

A single note on a particular kind of readers: the loners - we could trace the activities of a lot of lonely people, people to whom a collective, common space like this is probably the only chance to get some company and get the feeling of people moving around them.

\section{Differences and inequalities}

Another note to stress that the most economically dispossessed revealed a unique capacity to reflect (and cherish!) the opportunities offered by a public library, revealing also that their particular perspective was closely tied to their social positioning, what Haraway (1988) names the vantage points of the subjugated. They were also very concerned of hypothetical cuts in services, due to an ongoing privatization of public services.

When recently talking to a friend (male) librarian he expressed some concern for the fact that reading was progressively feminised. We could not find evidence to support this assumption. Although girls presently tend to qualify with higher classifications, and education is tightly tied to reading habits, both genders seemed represented during our field observations. On the other hand, a 
clear gender difference was perceived on the absence of middle-aged or elder women: unlike men and younger women their leisure is probably still strongly confined to domesticity. A single exception was a woman who lived for many years abroad where she got into the habit of visiting libraries.

Nor did we find evidence of segregation on account of ethnic differences; curiously a noisy and large group of African adolescents used to enter to access the Internet during lunch time. They came in during our stay and we tried to get to talk to them; in spite of our demand, the guards in the entrance did not signal them to us, when leaving; they just went out unnoticed, like any other users.

The workstation for the blind and amblyopic was appreciated, in spite of having a low use. A wide publicity and the elimination of physical barriers when crossing the garden should be taken into account.

Although, we did find some aspects that call for improvement: occasional visits by homeless men were triggering some fears of insecurity by users. We were told that some of them used to bath in the restrooms. As this is a municipal facility, users in need of special care or attention should be forwarded to social workers for advice and care but not be excluded from the a library. Our view is that these urban figures may embody the fear of the outcast and stranger, that is, subjective insecurity feelings are really fantasizing and amplifying real insecurity situations, Fernandes (2003). Symptomatically no real danger situation was ever reported in the premises, apart from the episode with the contours of an urban myth- an often told story of a fight with a gun between two immigrants, which the security staff assured had really never happened.

Some librarians told us that the homeless began constituting a problem from the moment they began entering in groups to watch movies, leading some users to complain about couches being used to sleep in and TV sets being occupied for too long. We could whiteness users sleeping in the (comfortable!) couches. But these «normal» users were not disturbed for that, the staff usually ignored it. As a consequence one TV set was removed from the multimedia area, another is used for documentaries, only two are left for feature films. We would advise a different approach, as watching a film is as good an activity as reading a book: to reinstall that TV set and have it play programmed and scheduled films, announced in advance. Conflicts around titles choices could be avoided and still have the room and used to its maximum capacity.

In spite of the architect's wish not to discriminate by floor height, signs of differentiation can traced attached, not to space, but to supports: multimedia requires less cultural capital, Bourdieu (1979), attitudes, body postures, are clear markers of a corporal hexis, Bourdieu $(1977,87)$ tied to social class.

\section{Concluding remarks}

Almeida Garret Public Library is being used as a civic centre, beyond a traditional role, no cultural or leisure activities should, a priori, be set aside. These new needs are to be best understood in the context of the city and present housing and life conditions.

Some valued dimensions of the library, from the users' point of view were: propitiation of a space fostering study and work through the provision of a stimulating collective environment, of order and tranquillity, the availability of collective free resources. Other positive characteristics were noted. As the allowed relaxed atmosphere and the possibility of coming in and out at one's ease is a clear advantage and existing surveillance does not curtail this. Readers cherish free public resources like this; most deprived users were, as might be anticipated, the most sensitive to this economic advantage. 
The urban location is also facilitating, although we'd say not determinant, judging by the number of readers that are driven in from neighbouring localities; easiness of public transportation, though, seems to be much appreciated. The library building is finely integrated in the surrounding garden, standing side-by-side in a good dialogue and nice reciprocal mingling.

The Library provides enough differentiation and flexibility for personal or group appropriation of space and resources for readers of different social conditions and differentiated expectations. Space provides at the same time privacy and conviviality, without imposing restrictions on group work, on social interchange and on collective enjoyment.

This atmosphere, welcoming for its scale, spatiality, light, materials and transparencies, while cultured in its balance and sober style.

Activities here should be faced not only as profiting from public but also from Commons goods: services, equipments, skills, cultural and informational resources are shared in a rational and sustainable way, as an example opposing the individualization which characterizes (and de-characterizes...) our daily lives. The possibility of housing a large diversity of uses must be deepened and cherished in order to stimulate the participation in a democratic public sphere that fosters the co-presence and the connection of these differences.

\section{References}

Bakardjieva, Maria, (2004),. Virtual togetherness: an everyday life perspective. In: Feenberg, Andrew, Ed. \& Barney, Darin, Ed. Community in the digital age: philosophy and practice. Rowman \& Littlefield. ISBN 0742529592.

Becker, Howard, (1996). The Epistemology of Qualitative Research. In: Richard Jessor, Anne Colby, And Richard A. Shweder. Ethnography and human development: context and meaning in social inquiry. Chicago: University of Chicago Press, p. 53-71. Also available from: <http://www.rnd.ncnu.edu.tw/hdcheng/research/quali/The\%20Epistemology\%20of \%20Qualitative\%20Research.htm>.

Bourdieu, Pierre. 1979. La distinction: critique sociale du jugement de goût. Paris: Les Éd. de Minuit. ISBN 2-7073-0275-9.

Bourdieu, Pierre (1977) Outline of a Theory of Practice. Cambridge: Cambridge University Press. p. 87

Bull, Michael, (2006). Investigating the culture of mobile listening: from Walkman to iPod. In: O'HARA, KENTON \& BROWN, BARRY. Consuming music together: social and collaborative aspects of music consumption technologies. Dordrecht: Springer, p. 131-149. ISBN 1402040318.

Calhoun, Craig, (2005). Rethinking the Public Sphere: Presentation to the Ford Foundation. [online]. Social Science Research Council. Also available from:

<http://www.ssrc.org/programs/calhoun/publications/Rethinking_the_Public_Sphere_05_speec h.pdf $>$.

Certeau, Michel de, (1990). L'invention du quotidien: art de faire. 2nd ed. Paris: Gallimard. ISBN 2-07-032576-8.

Donmoyer, Robert, (2000). Generalizability and the single case study. In: Gomm, Roger, Hammersley, Martyn \& Foster, Peter. Case study method. Sage, p. 45-68. ISBN 9780761964148.

Fernandes, Luís, (2003). A imagem predatória da cidade. In: Etnografias Urbanas. Oeiras: Celta, p. 53-62.

Geertz, Clifford, (1973). A interpretação das culturas. Rio de Janeiro: Zahar.

Haraway, Donna, (1991). A manifesto for cyborgs: science, technology and socialist feminism in the 1980s. In: Simians, cyborgs and women: the reeinvention of nature. New York: Routledge, p. 149-181.

Haraway, Donna, (1988). Situated knowledges: the science question in feminism and the prrivilege of partial perspective. Feminist Studies, vol. 14, no. 3, p. 575-599.

Kvale, Steinar, (1996). Interviews: an introduction to qualitative research interviewing. Thousands Oaks: Sage. ISBN 0-8039-5820-X.

Lefebvre, Henri, (2000 [1974]). La production de l'espace. 4ème ed. Paris: Anthropos. ISBN 27178-3954-2.

Petit, Michèle. 2001. Lecturas: del espacio íntimo al espacio público. México: Fondo de Cultura Económica. ISBN 96816637999789681663797.

Seale, Clive, ed., (2004). Researching Society and Culture. 2nd ed. Los Angeles: London. ISBN 
9780761941972.

Tonkiss, Fran, (2005). Space, the city and social theory: social relations and urban forms. Cambridge, MA: Polity. ISBN 9780745628264.

Wirth, Louis, (2001 [1938]). Urbanismo como modo de vida. In: FORTUNA, CARLOS. Cidade, cultura e globalização. $2^{\mathrm{a}}$ ed. Oeiras: Celta, p. 45-65.

Note; this is a pre-print editon for

Sequeiros, Paula. "User profiles: from a qualitative case study approach to providing a better service." In Qualitative and quantitative methods in libraries: Theory and applications: Proceedings of the international conference on QQML 2009, edited by A. Katsirikou and C. H. Skiadas, 163-171. Singapore: World Scientific Publishing, 2010. 